\title{
Duration of day-care attendance and acute respiratory infection
}

\author{
Tempo de permanência na creche e infecção \\ respiratória aguda
}

Sandra Costa Fuchs 1

Rita de Cássia Maynart 1

Lenara Ferreira da Costa 1

Adriana Cardozo 1

RejaneSchierholt 1

1 Departamento de Medicina Social, Faculdade de Medicina, Universidade Federal do Rio Grande do Sul Rua Ramiro Barcelos, 2600 sala 415, Porto Alegre, RS 90035-003, Brazil. fax $+55-51-330-1380$
Abstract Day-care attendance accounts for an increased frequency of acute respiratory infections (ARI), in numbers of both episodes and hospitalizations. In addition to day-care exposure, risk factors include age, siblings, and crowding. The purpose of this study was to investigate a possi ble association between duration of day-care exposure and ARI. A cross-sectional study was carried out to compared ARI rates for children exposed to day care and children cared for at home. Children with at least one parent working in a hospital were sampled from the hospitalrun day-care center and those cared for at home. An acute respiratory infection was defined as the presence of two or more signs or symptoms in the previous two weeks. Children exposed to the day-care center for 12 to 50 hours a week had a three to five times greater risk of developing ARI than those staying at home. This risk was assessed independently, taking soci oeconomic status, age, and number of si bl ings into account. Risk of respiratory illness and day-care attendance has been described el sewhere, but this study presents original findings related to duration of exposure. With a view towards reducing risk of ARI, improvements should be made in institutional day-care centers in Brazil, where family day care is still not available.

Key words Child Health; Acute respiratory infection; Day-care centers; Health Care

Resumo A freqüência à creche associa-se com maior número de epi sódios de infecção respi ratória e hospitalizações. Além da creche, a idade, a presença de irmãos e a aglomeração do ambiente são outras características i denti ficadas como fatores de risco. Neste estudo investigou-se a associação entre infecção aguda do trato respiratório (IRA) e o número de horas que a criança permanecia na creche. Investigou-se a prevalência de IRA entre crianças freqüentadoras da crechee entre aquel as cuidadas em casa através de um estudo transversal. Sel eci onou-sea amostra entre filhos de funcionários de um hospital com disponi bilidade de creche. Infecção respi ratória foi definida pela presença de pelo menos dois sinais ou sintomas ocorridos nas duas últimas semanas. Crianças expostas à creche por 12 a 50 horas semanais apresentaram um risco aproxi madamente três a cinco vezes maior deter uma infecção respiratória aguda. Este efei to mostrou-se independente do nível sócio-econômico dos pais, da presença de irmãos e da idade da criança. Outros estudos caracterizaram o risco decorrente da exposição à creche, contudo neste detectou-se o efeito relacionado a permanência prol ongada. Alternativas como as creches familiares americanas são pouco difundidas em nosso mei o, portanto, deve-se buscar mei os de minimizar o risco de IRA nas instituições tradicionais.

Palavras-chave Saúde da Criança; Infecção Respiratória Aguda; Creche; Cuidados de Saúde 


\section{Introduction}

Respiratory diseases are one of the main causes of hospitalization in children under five years of age. According to Cesar (1995), pneumonia was responsible for $3 \%$ of hospitalizations in children up to one year of age in the city of Pelotas, Rio Grande do Sul State. Characteristics such as age, presence of siblings, a crowded environment, and attendance at a day-care center were identified by Anderson et al. (1988) as risk factors for respiratory infection.

According to a study conducted by Wald et al. (1991), 13\% of children from two to three years of age attending day-care centers presented uncomplicated episodes of respiratory infection lasting over 15 days. Compared to children staying at home, Wald et al. (1988) found that children attending day-care centers developed at least six respiratory infections a year, remained sick for over sixty days, and presented at least four serious episodes of the illness. In two case-control studies, Fonseca et al. (1993) reported that day-care attendance was associated with a five-fold increase in the risk of pneumonia in the city of Fortaleza, and Victora et al. (1994) reported a nine-fold increase in the city of Porto Alegre.

Having characterized the impact of respiratory infections on preschool children, we sought to assess the association between acute respiratory infection and the number of hours spent in the day-care center.

\section{Material and methods}

A cross-sectional study was designed to simultaneously investigate day-care attendance, number of hours per week that the child remained in the day-care center, and prevalence

Figure 1

Theoretical model for investigating characteristics associated with acute respiratory infection (ARI).

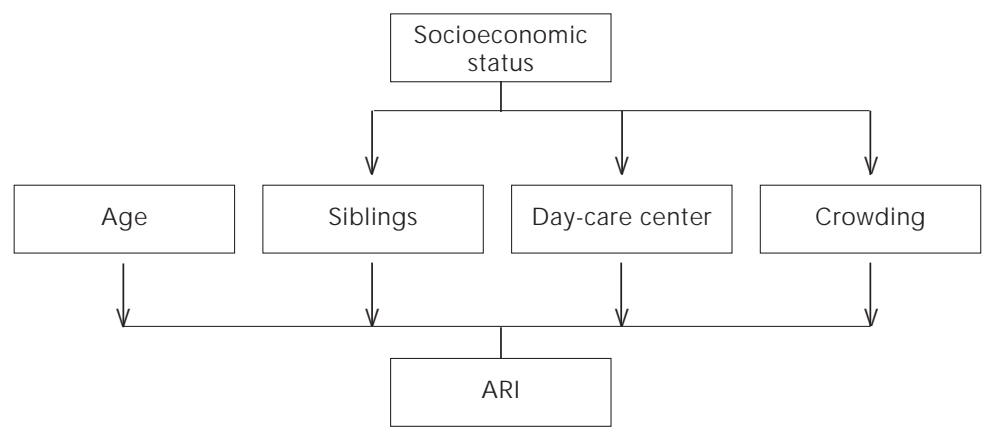

of acute respiratory infection. The target group consisted of children aged 1-5 years whose parents worked at the University Hospital in Porto Alegre. The children were randomly selected from two groups, those enrolled in the day-care center (using the center's register) and those not attending the center (contacting hospital employees who reported having children in this age bracket). We opted to study children of hospital employees because the parents' employment status made their children eligible for day care, thus reducing or eliminating interference from economic factors related to access to care.

We constructed a hierarchical theoretical model (Figure 1) to describe relations between attendance at the day-care center and acute respiratory infection (ARI) and to orient our analysis. In this model the family's socioeconomic status is the distal determinant of ARI and its complications, establishing housing conditions (a score of household goods) and the environment (crowding) where the child was born and is raised, followed by other determinants, like contact with siblings or with other children upon attending the day-care center. Thus, the independent effect of day-care attendance should be analyzed considering the other characteristics as confounding factors. Details on hierarchical modeling are described elsewhere, such as Victora et al. (1994) and Fuchs et al. (1996).

Acute respiratory infection was defined as the presence of at least two of the following signs or symptoms in the previous two weeks: axillary temperature $\geq 38^{\circ} \mathrm{C}$, cough, coryza, rales, dyspnea, tachypnea, and otitis as reported by one of the parents.

We investigated the association between acute respiratory infection and the following characteristics:

- sex and age;

- socioeconomic status: score of household goods, based on the sum of the number of rooms in the house, cars, electric and electronic home appliances (dishwasher, clothes drier, refrigerator, microwave oven, VCR, air conditioner, clothes washer, freezer, color TV, sound system with CD, computer, and telephone). The study also included the parents' level of schooling measured as the number of years completed (1-8, 9-11, and $\geq 12$ ) and crowding of the home environment, as assessed by the number of persons sleeping in the same room as the child $(1,2, \geq 3)$;

- history of disease: history of pneumonia (yes, no) and otitis (yes, no);

- current use of pacifier (yes, no); 
- environmental factors: presence of smokers in the household (measured by number of cigarettes consumed per day: 0, 1-20, 21-60), attendance at the day-care center (yes, no), number of hours spent at the day-care center in the previous two weeks, presence and number of siblings residing in the household.

These variables were obtained through an interview employing a standardized, precoded, previously tested questionnaire. As characteristics associated with risk of developing ARI, we considered those with a statistically significant " $p$ " ( $p<0.05$, two-tailed), using the chisquared or multivariate analysis, with a prevalence ratio (PR) different from one for the latter. In some analyses we adopted the linear trend test utilizing the same statistical criterion. The sample of 106 children provided a power of approximately $80 \%$ for detecting a prevalance ratio of 3.0 as statistically significant at 5\% (two-tailed), considering the proportion of 2.5 exposed to 1 non-exposed, and a prevalence of $14 \%$ for the disease among the non-exposed.

We obtained consent from the children's parents and the day-care center directors and guaranteed confidentiality of the information obtained through the interviews.

We analyzed the associations between the study characteristics and prevalance of acute respiratory infection using Pearson's chisquared test, with the SPSS-PC program. In order to study the independent effect of attendance at the day-care center in relation to confounding variables such as age, presence of siblings, crowding, and socioeconomic status, we employed a logistic regression analysis, using the EGRET program. The odds ratios obtained in the logistic regression were transformed into prevalence ratios (PR) using the formula described by Moreira (1994): PR = $\mathrm{OR} /(1+$ prevalence of event in the non-exposed $X(O R-1))$.

\section{Results}

We studied 106 children with a mean age of 3 years and 4 months, with a slight predominance of females (53\%). Table 1 shows how the sample included fewer children in the 24-35 month age bracket, and that there was a greater frequency of acute respiratory infections in this group.

The socioeconomic status of the children did not differ greatly for the categories (Table 2 ), except for the fact that $15 \%$ had a low score of household goods and $14 \%-17 \%$ of the par- ents had begun or concluded a university education. Children from families with lower scores of household goods had a higher frequency of respiratory infections (63\%), while the parents' level of schooling was not significantly associated with the presence of respiratory infection.

When assessing household exposure, we found that a larger number of persons sleeping

Table 1

Association between demographic characteristics and acute respiratory infection.

\begin{tabular}{lcc}
\hline Variables & $\mathrm{n}$ & ARI \\
\hline Age (months) & & \\
$12-23$ & 26 & $42 \%$ \\
$24-35$ & 13 & $62 \%$ \\
$36-47$ & 24 & $33 \%$ \\
$48-59$ & 25 & $48 \%$ \\
$60-71$ & 18 & $33 \%$ \\
p & & 0.5 \\
Sex & & \\
Male & & $38 \%$ \\
Female & 50 & $46 \%$ \\
p & 56 & 0.4 \\
\hline
\end{tabular}

Table 2

Association between socioeconomic characteristics and acute respiratory infection.

\begin{tabular}{lcc}
\hline Variables & $\mathrm{n}$ & ARI \\
\hline $\begin{array}{l}\text { Score of household goods } \\
\quad 8\end{array}$ & 16 & \\
$9-11$ & 36 & $63 \%$ \\
$12-14$ & 28 & $44 \%$ \\
$\geq 15$ & 26 & $41 \%$ \\
Linear trend test p & & $28 \%$ \\
Father's schooling (yrs.) & & 0.03 \\
$1-8$ & 39 & \\
$9-11$ & 45 & $51 \%$ \\
$\geq 12$ & 15 & $36 \%$ \\
$\mathrm{p}$ & & $33 \%$ \\
Mother's schooling (yrs.) & & 0.4 \\
$1-8$ & 32 & \\
$9-11$ & 55 & $39 \%$ \\
$\geq 12$ & 18 & $46 \%$ \\
p & & $33 \%$ \\
Crowding* & & 0.6 \\
1 & 27 & \\
2 & 51 & $31 \%$ \\
$\geq 3$ & 29 & $43 \%$ \\
Linear trend test & $\mathrm{p}$ & $52 \%$ \\
\hline
\end{tabular}

* Number of persons sleeping in same room with the child. 
Table 3

Disease and behavioral history associated with acute respiratory infection.

\begin{tabular}{lrr}
\hline Variables & $n$ & ARI \\
\hline Previous pneumonia & & \\
No & 81 & $40 \%$ \\
Yes & 25 & 0.3 \\
p & & \\
Previous otitis & & $37 \%$ \\
No & 41 & $46 \%$ \\
Yes & 65 & 0.3 \\
p & & \\
Uses pacifier & & $39 \%$ \\
No & 39 & $45 \%$ \\
Yes & 67 & 0.5 \\
p & & \\
No. of cigarettes & & \\
smoked by family & & $39 \%$ \\
0 & 63 & $50 \%$ \\
$1-20$ & 33 & 0.8 \\
$21-60$ & 10 & \\
p & & \\
\hline
\end{tabular}

in the child's bedroom did not significantly increase prevalence of ARI.

When we investigated the frequency with which the children had presented infectious respiratory diseases prior to the given episode, neither the use of a pacifier nor exposure to parents or relatives who smoked showed a statistically significant association with ARI (Table 3).

Overall prevalence of acute respiratory infection was $42 \%$, with $14 \%$ for children who did not attend the day-care center as compared to $53 \%$ for those who did. The children who had attended the center had stayed there for a mean of 68 hours in the previous two weeks (range was 24 to 100 hours). We found that attending the day-care center was associated with approximately twice the prevalence of acute respiratory infection; after adjusting for score of household goods, crowding, presence of siblings, and age, this association was approximately four-fold.

Attendance at the day-care center proved to be associated with prevalence of ARI and was three to five times greater as the number of hours spent there in the previous two weeks increased, regardless of the score of household goods, crowding in the household environment, the child's age, and presence of siblings.

Having more siblings living in the same household was not significantly associated with prevalence of ARI.

\section{Discussion}

This study confirms results published by Denny et al . (1986), Wald et al. (1988), Petersson \& Hakansson (1990), and Hurwitz et al. (1991) characterizing greater frequency of respiratory infection in children attending day-care centers. In addition, it demonstrates that prevalence of acute respiratory infection increased progressively for preschool children as they spent more time in a day-care center.

The children who had stayed 24 hours in the previous two weeks had been in the center for six hours on two different days of the week, and those who had spent the most time had been there for 10 hours a day. Hurwitz et al. (1991) had characterized a weekly mean of 34 hours in children from 18 to 59 months of age who attended a day-care center in Atlanta. Still, this Atlanta study failed to find a greater frequency of ARI among children who stayed at the day-care center for over 40 hours a week as compared to those who only stayed during the normal shift.

In our study, we found that time spent at the day-care center and prevalance of ARI were independent of other exposures, including the score of household goods, number of persons sleeping in the child's room, child's age, and presence of siblings. In the study by Hurwitz et al. (1991), the risk of respiratory infection varied from 1.3 (36-59 months) to 1.6 (6-17 months) for children attending an institutional day-care center as opposed to those in family day care. In addition, Fonseca et al. (1993) and Victora et al. (1994) found that risk of pneumonia as diagnosed radiologically was approximately 5 to 9 times greater among children attending day-care centers. However, in these two studies the children were under two years of age, and the authors did not investigate association with the number of hours spent at the centers.

Hurwitz et al. (1991) found that the presence of a greater number of siblings living in the same house reduced the incidence of ARI, particularly for children aged 36 to 59 months. In our study we detected a trend for children living with siblings to be protected against ARI, as compared to those with no siblings at home.

With regard to other confounding factors, we found that children with lower scores for household goods had a higher prevalence of ARI. A lower score for household goods appears to at least partially reflect a longer stay in the day-care center, which is more frequent among children from families of lower socioeconomic status. 
Environmental characteristics associated with risk of acute respiratory infection.

\begin{tabular}{|c|c|c|c|}
\hline Variables & $\mathrm{n}$ & $\begin{array}{c}\text { Non-adjusted PR } \\
(\mathrm{Cl}=95 \%)\end{array}$ & $\begin{array}{c}\text { Adjusted } \\
\text { PR* }\end{array}$ \\
\hline \multicolumn{4}{|l|}{ Day-care center } \\
\hline $\begin{array}{l}\text { No } \\
\text { Yes } \\
\text { p }\end{array}$ & $\begin{array}{l}29 \\
77\end{array}$ & $\begin{aligned} & 1.0 \\
1.8 & (1.4-2.4) \\
< & 0.001\end{aligned}$ & $\begin{aligned} & 1.0 \\
& 4.2 \\
< & 0.001\end{aligned}$ \\
\hline \multicolumn{4}{|c|}{$\begin{array}{l}\text { Hours spent in day-care } \\
\text { center in last } 14 \text { days }\end{array}$} \\
\hline $\begin{array}{l}0 \\
24-48 \\
49-60 \\
61-100 \\
p \\
\text { Linear trend test } p\end{array}$ & $\begin{array}{l}29 \\
12 \\
23 \\
42\end{array}$ & $\begin{array}{ll} & 1.0 \\
1.5 & (0.9-2.4) \\
2.0 & (1.2-3.2) \\
1.9 & (1.3-2.7) \\
& 0.003 \\
< & 0.001\end{array}$ & $\begin{aligned} & 1.0 \\
& 3.3 \\
& 5.3 \\
& 4.9 \\
< & 0.001 \\
< & 0.001\end{aligned}$ \\
\hline \multicolumn{4}{|c|}{ Number of siblings at home } \\
\hline $\begin{array}{l}0 \\
1 \\
2-9 \\
\text { Linear trend test } p\end{array}$ & $\begin{array}{l}57 \\
32 \\
17\end{array}$ & $\begin{array}{l}1.0 \\
0.9(0.5-1.4) \\
0.6(0.3-1.4) \\
\quad 0.18\end{array}$ & $\begin{array}{l}1.0 \\
0.7 \\
0.5 \\
0.09\end{array}$ \\
\hline
\end{tabular}

*Prevalence ratio adjusted for score of household goods, crowding, child's age, siblings,

and day-care center, using logistic regression

Parents of preschool children in our study had a higher mean level of schooling than described for parents of children attending the day-care centers in Rio Grande do Sul that were studied under the PIMES project (1993). In the latter, $58 \%$ of the parents had not finished primary school, and only $13 \%$ had finished primary school, while in our study $42 \%$ of the fathers and $52 \%$ of the mothers had begun or concluded secondary school. This difference in schooling may be due to the fact that at least one of the two parents was a university hospital employee.

A greater number of persons living in the household (particularly those sleeping in the same room with the child) produces greater exposure to respiratory infections. A relationship between more persons living in the household and increased incidence of lower respiratory tract illness has been shown by Anderson et al. (1988) and Victora et al. (1989), the latter having found an increase in death from pneumonia. Our study shows a trend for association between the number of persons sleeping in the child's bedroom and prevalence of ARI.

We were not able to detect a statistically significant assocation between respiratory infection and presence of smokers in the household. Victora et al . (1994) also failed to find an association between smoking in the household and pneumonia. Holberg et al. (1993) found that smoking by day-care attendants was asso- ciated with greater risk of rales among threeyear old children attending the center.

Our study was unique in showing that the number of hours per week spent at the day-care center increased the risk of ARI, and that this risk was independent of crowding at home, number of siblings, the child's age, and the material goods available in the household. Thus, close household contact with persons caring for the child (parents, grandparents, brothers and sisters, and babysitters) and with those sleeping in the same bedroom, even when facilitating exchange of pathogens, does not reach the same level as in transmission through interaction with other children in a day-care center, according to Haskins \& Kotch (1986). Since children will continue to attend day-care centers and it is unlikely that such attendance will be shortened (due to the parents' occupational demands), predictive factors for ARI should be studied in relation to the day-care centers' characteristics. The family day-care system, which is widespread in the United States and consists of no more than six children of the same age, may be one feasible alternative for Brazil. 


\section{References}

ANDERSON, L. J.; PARKER, R. A.; STRIKAS, R. A.; FARRAR, J. A.; GANGAROSA, E. J.; KEYSERLING, H. L. \& SI KES, R. K., 1988. Day-care center attendance and hospitalization for lower respiratory tract illness. Pediatrics, 82:300-308

CESAR, J., 1995. Hospitalizações por Pneumonia: Influência de Fatores Sócio-Econômicos e Gestacionais em uma Coorte de 5.304 Crianças no Sul do Brasil. Dissertação de Mestrado. Pelotas: Faculdade de Medicina, Universidade Federal de Pelotas.

DENNY, F. W.; COLLIER, A. M. \& HANDERSON, F. W., 1986. ARI in day care. Review of Infectious Diseases, 8:527-532.

FONSECA, W., 1993. Risk Factors for Childhood Pneumonia among the Urban Poor in Fortaleza, Brazil: A Case-Control Study. Tese de Doutorado. Londres: Faculty of Medicine, University of London.

FUCHS, S. C.; VICTORA, C. G. \& FACHEL, J. Modelo hierarquizado: uma proposta de modelagem aplicada à investigação de fatores de risco para diarréia grave. Revista de Saúde Pública, (in press).

HASKINS, R. \& KOTCH, J., 1986. Day care and illness: evidence, cost and public policy. Pediatrics, 77(Suppl.):51-82.

HOLBERG, C. J.; WRIGHT, A. L.; MARTINEZ, F. D. \& MORGAN, W. J. \&TAUSSI G L. M. 1993. Child care, smoking by caregivers, and lower respiratory tract illness in the first 3 years of life. Pediatrics, 91:885892.

HURWITZ, E. S.; GUNN, W. J.; PINSKY, P. F. \& SCHONBERGER, L. B., 1991. Risk of respiratory illness associated with day-care attendance: a nationwide study. Pediatrics, 87:62-69.
MOREIRA, L. B., 1994. Padrões de Consumo de Bebidas Al coólicas em uma Amostra Representativa da Região Urbana de Porto Alegre. Dissertação de Mestrado. Porto Alegre: Faculdade de Medicina, Universidade Federal do Rio Grande do Sul.

PETERSSON, C.\& HAKANSSON, A., 1990. A retrospective study of respiratory tract infection among children in different forms of day care. Scandinavian Journal of Primary Health Care, 8:119-122.

PIMES (Projeto Integrado para Menores de Seis), 1993. Avaliação da Qualidade das Instituições Voltadas ao Atendimento de Crianças de Zero a Seis Anos no Rio Grande do Sul. Plano Estadual de Atenção à Infância, 1993. Porto Alegre: Secretarias da Justiça, Trabalho e Cidadania, Governo do Estado do Rio Grande do Sul. (mimeo.).

VICTORA, C. G.; SMITH, P. G.; BARROS, F. C.; VAUGHAN, J. P. \& FUCHS, S. C., 1989. Risk factors for deaths due to respiratory infections among brazilian infants. International Journal of Epidemiology, 18:918-925.

VICTORA, C. G.; FUCHS, S. C.; FLORES, J. A.; FONSECA, W. \& KIRKWOOD, B., 1994. Risk Factors for Pneumonia among Brazilian children: a hierarchical analysis. Pediatrics, 93:977-985.

WALD, E. R.; DASHEFSKY, B.; BYERS, C.; GUERRA, N. \& TAYLOR, F., 1988. Frequency and severity of infections in day care. Journal of Pediatrics, 112:540-546.

WALD, E. R.; GUERRA, N. \& BYERS, C., 1991. Upper respiratory tract infection in young children: duration of and frequency of complications. Pediatrics, 87:129-133. 